\title{
EXPRESSION OF THE RENIN-ANGIOTENSIN SYSTEM COMPONENTS IN ONCOLOGIC DISEASES
}

\author{
Sergey Dolomatov ${ }^{1}$, Walery Zukow ${ }^{2}$, Nikolay Novikov ${ }^{3}$, Alexandra Markaryan ${ }^{1}$ and Elena Eremeeva ${ }^{1}$ \\ ${ }^{1}$ Department of Medical Biology, Medical Academy SI Georgievsky, Crimea Federal University, Simferopol, \\ Russian Federation jurisdiction; ${ }^{2}$ Faculty of Earth, Nicolaus Copernicus University, Torun, Poland; \\ ${ }^{3}$ A. Tsyb Medical Radiological Research Center, branch of the National Medical Research Radiological Center \\ of the Ministry of Health of the Russian Federation, Obninsk, Kaluga Region, Russian Federation
}

\begin{abstract}
SUMMARY - The literature devoted to changes in the expression of the renin-angiotensin system (RAS) proteins of cancer cells was analyzed. The dynamics of RAS protein expression in malignant tumors and the possible role of epigenetic mechanisms in these processes are briefly reviewed. Through research of the epigenetic mechanisms in cancer, principally new techniques for their correction based on the use of selective regulatory systems of covalent modification of histone proteins (for example, deacetylase inhibitor) and microRNA synthesis technologies have been developed. Literature data show promising pharmacological correction of epigenetic modification of chromatin in the treatment of cancer.
\end{abstract}

Key words: Oncology; Ectopic RAS cancer cells; Epigenetic stimulation of RAS in oncology

\section{Introduction}

According to the literature, the components of the renin-angiotensin system (RAS) may participate in the processes of neoplastic tissues, stimulate growth and metastasis of tumors ${ }^{1-4}$. Earlier studies have demonstrated diagnostic and prognostic value of analyzing the expression of RAS components in oncology ${ }^{5}$. A number of modern publications include reaffirmation of the research components of RAS in oncology in terms of diagnostic value of analyzing the expression of RAS components, prediction of the course of the disease and pharmacological effects on malignant tumors $^{1,2,6}$. Stimulation of local production of angiotensin-II (A-2), increase in the expression of A-2 receptors, rebalancing of the expression of angiotensin-Iconverting enzymes (ACE-1 and ACE-2) and their reaction products, and the level of $\mathrm{A}-2$ and $\mathrm{A}-1-7$ formation are regarded as the key pathogenic mecha-

Correspondence to: Walery Zukow, Faculty of Earth, Nicolaus Copernicus University, Toruń, Poland

E-mail:w.zukow@wp.pl

Received March 6, 2018, accepted March 29, 2018 nisms of growth and metastasis of malignant tumors ${ }^{1,7,8}$. The focus of some studies is assessing the risk of carcinogenesis induction by RAS inhibitors ${ }^{7,9-11}$. At the same time, the pathogenetic mechanisms that induce an increase in the expression of the RAS protein components in cell malignization, and their role in the processes of growth and metastasis of malignant tumors remain poorly understood.

\section{Diagnostic Value of RAS Protein Components in Oncology}

We consider it necessary to provide brief information on the diagnostic value of the analysis of the expression of the main components of RAS in various oncologic diseases.

\section{A-2 receptors}

In normal and pathologic conditions, A-2 exerts its influence through the AT1 and AT2 receptor populations. It has been established that in human astrocytoma cells, the detection rate of AT1 receptors in patients with high-grade malignancy (grades III and IV) 
increases to $67 \%$ versus $10 \%$ in the low-grade group, which positively correlates with the cell proliferation intensity and neoangiogenesis density ${ }^{12,13}$. In studies on experimental animals, in inoculated culture of colorectal cancer $(\mathrm{CRC})$ cells it was found that A-2 through the AT1 and AT2 receptors stimulated migration of malignant cells and their metastasis in the liver ${ }^{14}$. The cells of non-small cell lung cancer exhibiting high expression levels of the AT1 receptor have been reported to be resistant to the effects of cytostat$\mathrm{ics}^{15}$. Analysis of clinical observations suggests that increased expression of AT1 receptors by malignant cells indicates an unfavorable prognosis of the course of the disease because A1 effects are realized through AT1 receptors aimed at stimulating growth and metastasis of the tumor, i.e. neoangiogenesis ${ }^{8,17}$. It is emphasized that activation of the A-2/AT1 pathway for realization of the pre-oncogenic effects of A-2, which has a pleiotropic effect, has an impact on lymphocytes or tumorassociated macrophages, which leads to a decrease in anticancer immunity, and changes in the production of interleukins and proinflammatory cytokines ${ }^{4,17}$. A sharp, according to some data more than 100-fold increase in the transformed AT1 cells of the protein occurs due to the activation of the AGTR1 gene encoding the AT1 protein ${ }^{17}$. It is possible that the stimulation of neoangiogenesis, realized through the AT1 receptors, is one of the universal pathogenetic mechanisms of the progression of tumors of various genesis $^{4,18}$. There are data on the synergistic effects of AT1/A-2 and AT2/A-2 systems in the stimulation of neoangiogenesis ${ }^{19}$ and cell migration, inflammation and extracellular matrix formation via AT1 and AT2 receptors ${ }^{12}$. It has been shown that changes in the expression of AT1 and AT2 receptors are regarded as markers of malignancy of gastric mucosa, induced $\mathrm{He}$ licobacter pylori ${ }^{20}$, progression of oral tongue squamous cell carcinoma ${ }^{21}$, progression of colorectal cancer risk and metastasis ${ }^{22,23}$, diagnosis of lung cancer $^{24}$ and mammary gland cancer ${ }^{25}$. The level of A-2 receptor expression is regarded as a prognostic criterion for esophageal squamous cell carcinoma ${ }^{26}$ and renal clearcell carcinoma ${ }^{27}$. Along with this, according to some authors, in some cases, the mechanisms of change in the expression of AT1 and AT2 with tumor progression reflect a much more complex picture of the rearrangement of the malignant tissue sensitivity to the effects of humoral factors ${ }^{1,4,20,25,28}$.
It should be noted that in a number of modern review publications, results of the study of the specific features of AT1 and AT2 expression of A-2 receptors in various oncologic diseases, their diagnostic and prognostic value are interpreted in detail, arguments are presented in terms of their role in the pathogenesis of diseases, progression and dissemination of tumors, and the promise of clinical use of selective A-2 receptor antagonists in order to increase the effectiveness of chemotherapy, immunotherapy and neoangiogenesis inhibitors in oncology $y^{1,4,7,25,29}$.

\section{Angiotensin-I-converting enzyme (ACE-1)}

Angiotensin-I-converting enzyme (ACE), carboxydipeptidase, is one of the key factors involved in the conversion of angiotensin-I (A-1) into physiologically active angiotensin-II (A-2). However, in pathology, including cancer, the role of ACE in the formation of A-2 can be significantly reduced by increasing the contribution of the ACE-independent conversion path of A-1 to A-2 in the presence of chymase and other peptidases, increasing the resistance of tumor cells to anticancer therapies ${ }^{7,30,31}$. It is widely known that $\mathrm{ACE}$, having a relatively low substrate specificity, can participate not only in the formation of A-2, but also in kinins, as well as other physiologically active molecules that are potentially relevant to the processes of carcinogenesis, growth and dissemination of tumors $^{1,7}$. Attention is drawn to the information that $\mathrm{ACE}$, in addition to peptidase activity, can directly participate in the intracellular signal transduction of A-2, actually being a receptor of A-2 $2^{32}$. According to the authors of the cited publication, the mechanism of ACE-dependent reception A-2 can play an important role in managing the migration and proliferation of cancer cells. Consequently, the dynamics of changes in the topology and expression levels of $\mathrm{ACE}$ in cancer can serve as a marker for the localization of the prooncogenic effects of A-2 and other humoral factors, the metabolism of which is related to the functions of the components of the RAS. For example, in cancer of the kidneys, a regular change in the activity and topology of expression of ACE proteins has been observed $^{7,30}$. Normally, the epithelium of the cortical segments of the tubule of the nephron, in particular the epithelium of the proximal section, shows high rates of $\mathrm{ACE}$ expression, which is absent in the clear cell renal cell carcinoma (CCRCC) and is detected only in the 
blood vessels of the tumor ${ }^{30}$. The authors showed that the level of protein expression in the tumor and the magnitude of its enzymatic activity in plasma could serve as a marker in CCRCC patients and overall survival of CCRCC patients. On the other hand, inhibition of neoangiogenesis in malignant neoplasms by $\mathrm{ACE}$ blockers is considered as one of the main indications for the use of drugs in this group in oncology $y^{33}$. The results of experimental studies have shown that micro-contractions of tumor cells in mice vaccinated with intestinal cancer cells, which contribute to escape from anticancer immunity, are formed by macrophages and cancer-associated fibroblasts ${ }^{34}$. According to the authors, the expression level of ACE sharply increased in macrophages, which may indicate an increase in the intensity of the local production of immunosuppressive molecules, such as nitric oxide, TGF-b1, PGE2. Normally, the expression of ACE is critical for the formation of a specific microenvironment in the processes of cytodifferentiation at the stage of embryonic organ development or in intensively proliferating tissues. However, an excessively high level of expression is not only associated with impaired hematopoiesis, but is also considered as the effect of ACE in neoplastic hematologic diseases, including neoplastic hematopoie$\operatorname{sis}^{35}$. A significant increase in the expression of $\mathrm{ACE}$ in larynx cancer indicates an unfavorable course of the disease and a high risk of tumor metastasis ${ }^{36}$. Thus, changes in the expression of $\mathrm{ACE}$, both increase and decrease, along with the study of the ACE gene polymorphism, are widely used in modern oncology as a marker of the disease severity and prognosis ${ }^{1}$. However, according to some authors, the level of ACE expression by malignant tumor cells does not always correlate with the intensity of local production of A-2, due to the increased activity of chymase, which regulates ACE-independent pathway of A- 2 formation ${ }^{31}$. In addition, it is necessary to take into account that $\mathrm{ACE}$ is directly involved in the regulation of the body immune responses ${ }^{35}$.

\section{Angiotensin-I-converting enzyme-2 (ACE-2) and ACE2/Ang-(1-7)/MAS1 axis}

The ACE-2 homolog of ACE-1 is responsible for metabolic clearance of A-2; the enzyme is used as a substrate for the synthesis of angiotensin-1-7 (A-1-7). In turn, A-1-7, exercising regulatory effect through MAS1-receptors, has opposite vasotonic action and proinflammatory prosclerotic effects to A-2 ${ }^{37}$. Reducing the level of ACE-2 expression in breast cancer cells is considered as a marker of the severe form of the disease with a high risk of metastasis ${ }^{38}$. According to the authors, the level of expression of ACE-2 represents the degree of the ACE2/Ang-(1-7)/MAS1 axis influence to limit transformation of calcium-dependent intracellular signaling pathways characteristic of the process of malignant transformation of cells. It was shown that the expression level of ACE-2 was negatively correlated with the intensity of neoangiogenesis in non-small cell lung cancer and the sensitivity of tumor cells to cytostatics. The ACE2/Ang-(1-7)/MAS1 axis has an inhibitory effect on VEGFa and matrix metalloproteinases MMP-2 and MMP-9 secretion, aids in limiting neoangiogenesis, increases the sensitivity of tumors to cytostatic drugs, and reduces the risk of metastasis ${ }^{39,40}$. A number of publications indicate that hypoxia is a hallmark of solid tumors and that hypoxia conditions contribute to strengthening the pro-oncogenic effect of ACE-1/A-2 against the background of reducing the effects of ACE-2/Ang-(1-7)/ MAS1 axis $^{41}$. The authors of the cited publication showed that hypoxia in vitro in Lewis lung carcinoma cell culture contributed to a decrease in the expression of ACE-2 and ACE/A-2/AT1-dependent induction of VEGF. Arguments are made in favor of the promising clinical use of A-1-7 as a factor in anticancer treatment of breast tumors the cells of which do not express estrogen receptor, progesterone receptor and human epidermal growth factor receptor- $2^{42}$. Some reviews also contain positive assessment of the prospects for the ACE2/Ang-(1-7)/MAS1 axis in anticancer pharmacology ${ }^{1}$. At the same time, it is emphasized that the nature of the influence of ACE-2/Ang-(1-7)/MAS1 axis on cancer cells and tumor progression may depend on the location of the tumor ${ }^{7,29,35}$. In particular, there is evidence that A-1-7 stimulates the migration of renal cell carcinoma (RCC) cells, up-regulation of proinflammatory genes, has a significant impact on RCC development and progression ${ }^{7}$. The authors tend to conclude that A-1-7 with respect to RCC has a prooncogenic effect.

\section{Angiotensinogen}

Angiotensinogen $(\mathrm{Agt})$ is the universal precursor of A-2 and A-1-7. Normally, Agt is mainly synthesized in the liver. In cancer, the liver typically remains 
the main source of $\mathrm{Agt}^{26}$. However, of interest are data on the diagnostic value of Agt local products as a marker of carcinogenesis. Particular metabolic Agt cancer cells have also attracted attention. On the one hand, Agt is regarded as one of the most informative markers of tumor neoangiogenesis activity ${ }^{40,42,43}$. On the other hand, according to the cited publications, a dominant Agt conversion product in tumor tissues is A-2. Thus, the combined effect of HIF-1-alpha and A-2 against the higher production of Agt is considered as the basic pathogenetic mechanism of stimulation of growth factors (especially VEGFa) activating tumor neoangiogenesis. Indeed, the results of clinical studies have shown that, firstly, overexpression of Agt gene in glioblastoma patients can be regarded as a marker of tumor resistance to anti-cancer therapy based on the inhibition of tumor neoangiogenesis ${ }^{44}$. Secondly, higher Agt gene expression in tumor tissue is accompanied by increased local production of A-2. However, there are literature data that Agt possesses the ability to inhibit neoangiogenesis ${ }^{29}$. When discussing local products of Agt, it is necessary to clarify that, according to some authors, stimulation of the local expression of RAS components, including Agt, is considered as a central inducer of intracellular cascade of regulatory proteins that determine the processes of malignancy and metastatic cells ${ }^{21}$. Moreover, the reported results do not preclude the activation of intracellular metabolism and adjustment of RAS components in cancer cells $s^{45}$, which is consistent with the opinion on the universal pathogenetic role of the activation of intracellular RAS, also implicating modulation of the gene expression processes ${ }^{46,47}$. However, tissue-specific expression patterns are emphasized in Agt as a marker of cancer risk. In particular, the risk of lung cancer is associated with reduction of protein production $^{48}$. According to the authors, epigenetic mechanisms of gene expression reducing Agt and point mutations of the gene can be considered as factors that increase the risk of lung cancer. Perhaps the dynamics of local production of Agt and its plasma levels may be different from the prognosis of metastatic colorectal cancer ${ }^{49}$. The authors found that the increasing serum Agt levels were significantly associated with worse overall survival, and epithelial expression of Agt was significantly associated with improved progression-free survival. Another aspect of the diagnostic value of the local production of Agt in tumor tissues may be due to natural variation of Agt gene expression, as the disease increases the risk of lung can$\mathrm{cer}^{26}$. The authors found that increasing serum Agt levels were significantly associated with worse overall survival, and epithelial expression of Agt was significantly associated with improved progression-free survival ${ }^{49}$.

\section{(Pro)renin}

Recently, the (pro)renin molecule and its receptors are attracting increasing attention not only as a regulatory RAS enzyme but also as an important element of ontogenesis control mechanisms of wound healing and pathogenesis of several diseases ${ }^{2}$. Some reviews on the pathogenetic role of RAS in cancer patients found important information about the impact of renin on the processes of malignancy cells and tumor progres$\operatorname{sion}^{21,29}$. In vitro studies have shown that renin may have a stimulating effect on cell growth in renal carcinoma cell culture ${ }^{51}$. Expression of renin can be considered as a marker of normal maturation of blood cells or their precursors of malignancy ${ }^{35}$. The authors of the cited survey emphasize that renin expression was detected in acute myeloid leukemia blast cells, in cells of chronic myeloid leukemia and acute lymphoid leukemia. It is reported that bone marrow progenitors express renin and become the source of lymphoblastic leukemia ${ }^{50}$. Renin progenitors have been identified in mouse bone marrow, giving rise to B-cell leukemia ${ }^{50}$. There are data that the renin gene expression in normal and malignant hematopoiesis can be controlled by epigenetic mechanisms ${ }^{35,50}$. In the context of the topic, it is relevant to recall that complex functioning, relatively little studied, of the receptor system to the (pro) renin is relevant not only to the RAS but also to the regulation of gene expression of the protein inductor processes of inflammation and tissue fibrosis ${ }^{51,52}$. Further studies confirmed the RAS-independent effects of the receptor system for (pro)renin, demonstrating their fundamental role in the regulation of cell homeostasis control mechanisms ${ }^{53}$. It was also found that plasma levels of (pro)renin receptor $((\mathrm{P}) \mathrm{RR})$ in the cancer patient group were dramatically increased ${ }^{54}$. Based on the analysis of the dynamics of $(P) R R$ expression in cells at various stages of malignancy, the authors concluded that $(\mathrm{P}) \mathrm{RR}$ may be profoundly involved in ductal tumorigenesis in the pancreas. Results of studying in vitro expression of $(\mathrm{P}) \mathrm{RR}$ in cultured human glioma cell suggest that this receptor may be 
both a prognostic marker and a therapeutic target for glioma $^{55}$. Data on change in the expression of $(\mathrm{P}) \mathrm{RR}$ in the process of hematopoiesis may be regarded as a promising diagnostic marker for promyelocytic leukemia $^{35}$.

\section{Epigenetic Mechanisms as Possible Regulators of Expression of RAS Components in Oncology}

The above summary of the dynamics of the expression of RAS components in tumor tissues indicates that, firstly, this figure can rise significantly in tissue, which normally does not have high levels of expression of RAS components ${ }^{21,22,54,56,57}$. Conversely, in certain oncologic diseases, cells gradually lose their inherent ability to express normal RAS proteins ${ }^{7,30}$. Secondly, there is regular expression and topology change of RAS proteins in tumor tissues, depending on the current stage and severity of the disease $e^{26,35,55}$. A number of publications provide evidence for the leading role of epigenetic mechanisms in the change of the synthesis of proteins capable of stimulating the processes of malignancy, inflammation, fibrosis, and metastasis ${ }^{35,58-62}$. In this case, attention is paid to the restructuring epigenetic gene expression of RAS components in the processes of malignancy and growth of cancer cells $^{31,35,58,59}$. Epigenetic reorganization of the expression of RAS components is a relatively new and littlestudied area in oncology. Normally, the impact on the dynamics of epigenetic mechanisms of gene expression of RAS proteins is observed in early stages and histologic organogenesis and in intensively proliferating tissues ${ }^{35,50}$. It is reported that one of the universal inducers of gene expression of RAS components of proteins, i.e. progression of malignant neoplasms, can be HIF-1alpha ${ }^{31,43,58}$. Several factors related to diabetes have also been found to affect the expression of genes of RAS proteins, increasing the risk of cancer ${ }^{29,63-65}$. It is possible that HIF-1alpha directly participates in the regulation of expression of angiotensinogen $(\mathrm{Agt})^{43}$. In turn, Agt is required for the increased production of A-2, stimulating tumor neovascularization and metastasis by AT1 receptors. It is reported that olmesartan, an AT1-receptor antagonist, could up-regulate miR205 and inhibit VEGF-expression and cancer cells ${ }^{57}$. Consequently, A-2 may be considered as a regulator of the transcription process. Indeed, experimental studies have shown that A-2 can enhance the production of proinflammatory cytokines (IFN $\gamma, \mathrm{TNF} \alpha$ ) and matrix metalloproteinases (MMP2, MMP9), stimulating cancer cell adhesion to endothelial cells, trans-endothelial migration and tumor cell migration across extracellular matrix ${ }^{66}$. Along with this, universality of epigenetic adjustment of the expression of RAS components in pathogenesis including cancer has been suggested $^{64,67}$. On the other hand, there are data on the epigenetic effects of A-1-7, limiting the mobility of cancer cells and their ability to metastasize ${ }^{68}$. From this perspective, of particular importance are data on the ability of ACE-1 to participate in intracellular signaling mechanisms of $\mathrm{A}-2^{32}$. No less relevant is the importance of the (pro)renin-(pro)renin receptor information systems in the control of gene expression, regardless of the state of RAS activity ${ }^{52,53}$. The results of other studies confirm the thesis that the (pro)renin(pro)renin receptor system has an important function in cancer pathogenesis and progression ${ }^{54,69,70,72,73}$.

\section{Oncologic Aspects of Expression of RAS Components and Local Renin-Angiotensin System}

The concept of 'local races' was formed as an idea of the element inorganic humoral complex homeostatic control of body functions. This point of local renal RAS can be illustrated by the following example. Normally, appropriate stimulus for activation of intrarenal RAS has two distinct mechanisms: a renal baroreceptor and sodium chloride delivery to the macula densa. As a result, it increases secretion of the cell juxta-glomerular apparatus RAS regulatory enzyme renin and increases production of A-2. Basic renotropic physiologic effects of A-2 are exerted mainly on the parameters of renal hemodynamics and filtration processes at proximal nephron, including initiation effects through controlling transcription regulatory proteins and transport in proximal nephrocytes ${ }^{71,72}$. Under physiologic conditions, the induction of renin secretion ${ }^{73}$ and stimulation of the A-2 transcription transport proteins tubular epithelium ${ }^{74}$ are adequate to the current state of the body water-salt balance. For example, a dietinduced hyponatrium physiologic stimulation of RAS is not reflected by increased urinary Agt or development of renal injury ${ }^{74}$. Consequently, the end result of a complex set of activities of humoral regulators of intrarenal homeostatic control system is to maintain 
stable blood pressure parameters, ion homeostasis, acid-base equilibrium and constant volume of extracellular body fluids ${ }^{72,73,75,76}$, induction of renin secretion ${ }^{73}$ and stimulation of the A-2 transcription transport protein tubular epithelium ${ }^{74}$ adequate to the current state of the body water-salt balance.

On the other hand, hypoxia, oxidative stress, high blood glucose levels, and other adverse factors are capable of inducing epigenetic mechanisms of activation of inflammation and fibrosis of renal parenchyma, including topology change RAS components through gene expression control mechanisms $s^{65,77,78}$. An important result of these events is strengthening of renin secretion in renal parenchyma ${ }^{79}$, arteriolar smooth muscle cells, mesangial cells and interstitial cells by epigenetic gene expression control mechanisms $s^{47,73}$. Renin is a regulatory enzyme for RAS determining the intensity of further A-2 production. The accumulation of reactive oxygen species (ROS) in tissue enhances renal excretion of Agt in urine, reinforcing feedback loop between ROS activation and subsequent activation of ROS synthesis of $\mathrm{Agt}^{80}$. It is shown that the infusion of animal A-2 is essential to activate the biosynthesis of Agt by proximal nephrocytes, leading to further increase in tubular products of A-2 and enhancing its pathogenic influence ${ }^{81}$. In general, accumulation of RAS components in proximal nephrocytes increased intracellular production of A-2 and its effects on the transcription process, mitochondrial function, amplification of ROS products as one of the basic pathogenetic mechanisms of homeostatic disturbances of kidney function ${ }^{46,82,83}$. Renal excretion of Agt is recommended to be used as a diagnostic criterion for pathologic transformation of intrarenal $\mathrm{RAS}^{82,84,85}$.

Thus, pathologic intrarenal RAS transformation is carried out as follows: 1) under the control of epigenetic mechanisms that alter transcription processes, including RAS protein components; 2) the advent of ectopic foci biosynthesis of key components of RAS proteins; 3) strengthening of intracellular production of A-2 and increasing its influence on the transcription of proteins; and 4) weakening the expression of ACE- 2 and decreased production of A-1-7, the effects of which are opposite to A-2.

As a result, in contrast to physiologic conditions, pathologic change in topology and level of expression of RAS components leads to the following: 1) emergence of ectopic foci and increased intracellular RAS tubular epithelium; 2) formation of ectopic foci RAS (renin, angiotensinogen) facilitates the escape of trigger for RAS activation in respect of regulatory stimulant settings of body water-salt balance and hemodynamics; 3 ) interaction of ectopic foci of RAS remains, but this interaction is not directed to maintaining homeostasis, but it further provides unlimited induction of expression of RAS components and other regulatory proteins that promote fibrosis, inflammation and hypertrophy of the renal parenchyma cells; and 4) there is transformation of intracellular signal transduction systems ${ }^{72}$ and balance of the A-2 and A-1-7 regulatory action in the direction of enhancing the activity of ACE-1 and alpha-chymase on lower ACE expres$\operatorname{sion}^{73}$. Note that these changes occur as a result of adjustment of the expression of RAS components in tumor cells inducing cell malignancy, fibrosis, and tissue inflammation, neoangiogenesis, metastasis and immunosuppression ${ }^{1,4,7}$. Also, in the pathogenesis and progression of renal failure, the components of RAS cancer cells are not involved in performing homeostatic functions.

From the point of view of practical medicine, it comes to expediency of utilizing RAS blockers in the treatment of cancer. In our opinion, some aspects can be distinguished in this respect. On the one hand, enhancement of expression of ectopic foci of cancer cells, RAS, at first glance, gives reason to expect performance using $\mathrm{ACE}$ inhibitors and A-2 receptor antagonists in the treatment of cancer. Indeed, monotherapy with RAS blockers in cancer may exhibit relatively moderate therapeutic result. It is reported how to enhance the anticancer effects of RAS inhibitors in combination with chemotherapy and immunotherapy ${ }^{4}$. Along with this, it indicates the potential risks associated with the use of certain RAS blockers in the treatment of specific cancers ${ }^{7}$, up to their use being considered completely inappropriate ${ }^{86-88}$. On the other hand, qualitatively different methods may be developed for their pharmacological correction based on epigenetic mechanisms modulating and suppressing ectopic RAS activity ${ }^{89,90}$. Based on the analysis of the nature of the expression of the RAS ectopic foci, there is a concept of the universal role of epigenetic mechanisms in the pathogenesis of ectopic formation of RAS in oncologic and non-oncologic diseases ${ }^{65,67,91}$. Promising methods of treating cancer, completely based on the epigenetic mechanisms using synthetic microRNA 
have been postulated ${ }^{59,92}$. There are new prospects for the use of selective modulators of epigenetic processes in medical practice and of interest in oncology, confirming information on the readiness of application of this group of pharmacological agents (deacetylase inhibitors) in preclinical trials ${ }^{93}$.

\section{Conclusion}

A review of the literature has shown that the variation of the expression of RAS components is closely related to the pathogenesis of neoplastic transformation of cancer cell progression, as well as stimulation of the processes of metastasis. Information on the state of expression of protein RAS components contributes to the understanding of the mechanisms of carcinogenesis and dissemination of tumor cells. These data allow the use of qualitative and quantitative expression parameters of RAS components as markers of cancer severity. Tight engagement of RAS components in carcinogenesis was the basis for using the RAS inhibitor (ACE inhibitor-1 receptor antagonists and A-2) in therapy of cancer. However, analysis of the causes of changes in the expression of RAS protein in tumor cells has revealed that very significant function belongs to epigenetic mechanisms of regulation of gene expression in these processes. Through research of epigenetic mechanisms in cancer, new techniques for their correction have been developed principally based on the use of selective regulator systems of covalent modification-histone proteins (e.g., deacetylase inhibitor) and microRNA synthesis technology. The published data on the pharmacological properties of these drugs suggest their prospects for effective treatment of cancer.

\section{References}

1. Regulska K, Stanisz B, Regulski M. The renin-angiotensin system as a target of novel anticancer therapy. Curr Pharm Des. 2013;19(40):7103-25, http://dx.doi.org/10.2174/1381612811 3199990508

2. Gomez RA, Sequeira-Lopez MLS. Novel functions of renin precursors in homeostasis and disease. Physiology (Bethesda). 2016;31(1):25-33, http://dx.doi.org/10.1152/physiol.00039.2015Kouchi

3. Pinter M, Weinmann A, Wörns M-A, et al. Use of inhibitors of the renin-angiotensin system is associated with longer survival in patients with hepatocellular carcinoma. United European Gastroenterol J. 2017;5(7):987-96, http://dx.doi.org/10.1177/2050640617695698

4. Pinter M, Jain RK. Targeting the renin-angiotensin system to improve cancer treatment: implications for immunotherapy. Sci Transl Med. 2017;9(410):eaan5616, http://dx.doi.org/10.1126/scitranslmed.aan5616

5. Romer FK. Angiotensin-converting enzyme and its association with outcome in lung cancer. Br J Cancer. 1981;43:135-42.

6. Tawinwung S, Ninsontia C, Chanvorachote P. Angiotensin II increases cancer stem cell-like phenotype in lung cancer cells. Anticancer Res. 2015;35(9):4789-97.

7. Sobczuk P, Szczylik C, Porta C, Czarnecka AM. Renin angiotensin system deregulation as renal cancer risk factor. Oncol Lett. 2017;14(5):5059-68, http://dx.doi.org/10.3892/ol.2017.6826

8. Sun H, Li T, Zhuang R, et al. Do renin-angiotensin system inhibitors influence the recurrence, metastasis, and survival in cancer patients? Evidence from a meta-analysis including 55 studies. Medicine (Baltimore). 2017;96(13):e6394, http://dx. doi.org/10.1097/MD.0000000000006394

9. Connolly S, Yusuf S, Swedberg K, et al. Effects of telmisartan, irbesartan, valsartan, candesartan, and losartan on cancers in 15 trials enrolling 138,769 individuals. ARB Trialists Collaboration. J Hypertens. 2011;29(4):623-35, http://dx.doi.org/ 10.1097/HJH.0b013e328344a7de

10. Azoulay L, Assimes TL, Yin H, et al. Long-term use of angiotensin receptor blockers and the risk of cancer. PLoS One. 2012;7(12):e50893, http://dx.doi.org/10.1371/journal.pone.0050893

11. Yang Y, Zhang F, Skrip L, et al. Lack of an association between angiotensin receptor blocker based therapy and increased risk of cancer: evidence from large observational studies. PLoS One. 2015;10(3):e0119775, http://dx.doi.org/10.1371/journal. pone. 0119775

12. Aydiner A, Ciftci R, Sen F. Renin-angiotensin system blockers may prolong survival of metastatic non-small cell lung cancer patients receiving erlotinib. Medicine (Baltimore). 2015;94 (22):e887, http://dx.doi.org/10.1097/MD.0000000000000887

13. Arrieta O, Pineda-Olvera B, Guevara-Salazar P, et al. Expression of AT1 and AT2 angiotensin receptors in astrocytomas is associated with poor prognosis. Br J Cancer. 2008;99(1):160-6, http://dx.doi.org/10.1038/sj.bjc.6604431

14. Nguyen L, Ager EI, Neo J, Christophi C. Regulation of colorectal cancer cell epithelial to mesenchymal transition by the renin angiotensin system. J Gastroenterol Hepatol. 2016; 31(10):1773-82, http://dx.doi.org/10.1111/jgh.13307

15. Cheng Q, Zhou L, Zhou J,et al. ACE2 overexpression inhibits acquired platinum resistance-induced tumor angiogenesis in NSCLC. Oncol Rep. 2016;36(3):1403-10, http://dx.doi.org/10.3892/or.2016.4967

16. Keizman D, Huang P, Eisenberger MA, et al. Angiotensin system inhibitors and outcome of sunitinib treatment in patients 
with metastatic renal cell carcinoma: a retrospective examination. Eur J Cancer. 2011;47(13):1955-61, http://dx.doi.org/10.1016/j.ejca.2011.04.019

17. Coulson R, Liew SH, Connelly AA, et al. The angiotensin receptor blocker, losartan, inhibits mammary tumor development and progression to invasive carcinoma. Oncotarget. 2017;8 (12):18640-56, http://dx.doi.org/10.18632/oncotarget.15553

18. Osumi H, Matsusaka S, Wakatsuki T, et al. Angiotensin II type-1 receptor blockers enhance the effects of bevacizumabbased chemotherapy in metastatic colorectal cancer patients. Mol Clin Oncol. 2015;3(6):1295-300, http://dx.doi.org/10.3892/mco.2015.630

19. Ager EI, Wen SW, Chan J, et al. Altered efficacy of AT1Rtargeted treatment after spontaneous cancer cell-AT1R upregulation. BMC Cancer. 2011;11:274, http://dx.doi.org/10.1186/1471-2407-11-274

20. Sugimoto M, Yamaoka Y, Shirai N, Furuta T. Role of reninangiotensin system in gastric oncogenesis. J Gastroenterol Hepatol. 2012;27(3):442-51, http://dx.doi.org/10.1111/j.1440-1746.2011.06964.x

21. Itinteang T, Dunne JC, Chibnall AM, et al. Cancer stem cells in moderately differentiated oral tongue squamous cell carcinoma express components of the renin-angiotensin system. J Clin Pathol. 2016;69(10):942-5, http://dx.doi.org/10.1136/ jclinpath-2016-203736

22. Kuniyasu H. Multiple roles of angiotensin in colorectal cancer. World J Clin Oncol. 2012;3(12):150-4, http://dx.doi.org/10.5306/wjco.v3.i12.150

23. Shimizu Y, Amano H, Ito Y, et al. Angiotensin II subtype 1a receptor signaling in resident hepatic macrophages induces liver metastasis formation. Cancer Sci. 2017;108:1757-68, http://dx.doi.org/10.1111/cas.13306

24. Gallagher PE, Cook K, Soto-Pantoja D, et al. Angiotensin peptides and lung cancer. Curr Cancer Drug Targets. 2011; 11(4):394-404.

25. Vinson GP, Barker S, Puddefoot JR. The renin-angiotensin system in the breast and breast cancer. Endocr Relat Cancer. 2012;19 (1):R1-R19, http://dx.doi.org/10.1530/ERC-11-0335

26. Li S-H, Lu H-I, Chang AYW, et al. Angiotensin II type I receptor (AT1R) is an independent prognosticator of esophageal squamous cell carcinoma and promotes cells proliferation via mTOR activation. Oncotarget. 2016;7(41):67150-65, http:// dx.doi.org/10.18632/oncotarget.11567

27. Dolley-Hitze T, Jouan F, Martin B, et al. Angiotensin-2 receptors (AT1-R and AT2-R), new prognostic factors for renal clear-cell carcinoma? Br J Cancer. 2010;103(11):1698-705, http://dx.doi.org/10.1038/sj.bjc.6605866

28. Rhodes DR, Ateeq B, Cao Q et al. AGTR1 overexpression defines a subset of breast cancer and confers sensitivity to losartan, an AGTR1 antagonist. Proc Natl Acad Sci U S A. 2009;106(25):10284-9, http://dx.doi.org/10.1073/pnas.0900351106

29. Wegman-Ostrosky T, Soto-Reyes E, Vidal-Millán S, SánchezCorona J. The renin-angiotensin system meets the hallmarks of
cancer.J Renin Angiotensin Aldosterone Syst. 2015;16:227-33, http://dx.doi.org/10.1177/1470320313496858

30. Errarte P, Beitia M, Perez I, et al. Expression and activity of angiotensin-regulating enzymes is associated with prognostic outcome in clear cell renal cell carcinoma patients. PLoS One. 2017;12(8):e0181711, http://dx.doi.org/10.1371/journal.pone.0181711

31. Xie G, Liu Y, Yao Q, et al. Hypoxia-induced angiotensin II by the lactate-chymase-dependent mechanism mediates radioresistance of hypoxic tumor cells. Sci Rep. 2017;7:42396, http://dx.doi.org/10.1038/srep42396

32. de Alvarenga EC, de Castro Fonseca M, Coelho Carvalho C, et al. Angiotensin converting enzyme regulates cell proliferation and migration. PLoS One. 2016;11(12):e0165371, http://dx. doi.org/10.1371/journal.pone.0165371

33. Shen J, Huang Y-M, Wang M, et al. Renin-angiotensin system blockade for the risk of cancer and death. J Renin Angiotensin Aldosterone Syst. 2016;17(3):1-14, http://dx.doi.org/10.1177/1470320316656679

34. Nakamura K, Yaguchi T, Ohmura G, et al. Involvement of local renin-angiotensin system in immunosuppression of tumor microenvironment. Cancer Sci. 2018;109(1):54-64, http://dx.doi. org/10.1111/cas.13423

35. Haznedaroglu IC, Malkan UY. Local bone marrow renin-angiotensin system in the genesis of leukemia and other malignancies. Eur Rev Med Pharmacol Sci. 2016;20(19):4089-111.

36. Han $\mathrm{C}, \mathrm{Ge} \mathrm{W}$. Up-regulation of angiotensin-converting enzyme (ACE) enhances cell proliferation and predicts poor prognosis in laryngeal cancer. Med Sci Monit. 2016;22:4132-8, http://dx.doi.org/10.12659/MSM.896933

37. Clarke NE, Turner AJ. Angiotensin-converting enzyme 2: the first decade. Int J Hypertens. 2012;307315 Article ID307315, http://dx.doi.org/10.1155/2012/307315

38. Yu C, Tang W, Wang Y, et al. Downregulation of ACE2/Ang(1-7)/Mas axis promotes breast cancer metastasis by enhancing store-operated calcium entry. Cancer Lett. 2016;376(2): 268-77, http://dx.doi.org/10.1016/j.canlet.2016.04.006

39. Cheng Q, Zhou L, Zhou J, et al. ACE2 overexpression inhibits acquired platinum resistance-induced tumor angiogenesis in NSCLC. Oncol Rep. 2016;36:1403-10, http://dx.doi.org/10.3892/or.2016.4967

40. Feng Y, Ni L, Wan H, et al. Overexpression of ACE2 produces antitumor effects via inhibition of angiogenesis and tumor cell invasion in vivo and in vitro. Oncol Rep. 2011;26:1157-64, http://dx.doi.org/10.3892/or.2011.1394

41. Fan L, Feng Y, Wan HY, et al. Hypoxia induces dysregulation of local renin-angiotensin system in mouse Lewis lung carcinoma cells. Genet Mol Res. 2014;13(4):10562-73, http:// dx.doi.org/10.4238/2014.December.12.19

42. Luo Y, Tanabe E, Kitayoshi M, et al. Expression of MAS1 in breast cancer. Cancer Sci. 2015;106(9):1240-8, http://dx.doi. org/10.1111/cas.12719 
43. Choi J-H, Nguyen M-P, Lee D, et al. Hypoxia-induced endothelial progenitor cell function is blunted in angiotensinogen knockout mice. Mol Cells. 2014;37(6):487-96, http://dx.doi. org/10.14348/molcells.2014.0119

44. Urup T, Michaelsen SR, Olsen LR, et al. Angiotensinogen and HLA class II predict bevacizumab response in recurrent glioblastoma patients. Mol Oncol. 2016;10(8):1160-8, http:// dx.doi.org/10.1016/j.molonc.2016.05.005

45. Blanco L, Sanz B, Perez I, et al. Altered glutamyl-aminopeptidase activity and expression in renal neoplasms. BMC Cancer. 2014;14:386, http://dx.doi.org/10.1186/1471-2407-14-386

46. Ellis B, Li XC, Miguel-Qin E, et al. Review: Evidence for a functional intracellular angiotensin system in the proximal tubule of the kidney. Am J Physiol Regul Integr Comp Physiol. 2012;302(5):R494-R509,

http://dx.doi.org/10.1152/ajpregu.00487.2011

47. De Mello WC. Chemical communication between heart cells is disrupted by intracellular renin and angiotensin II: implications for heart development and disease. Front Endocrinol (Lausanne). 2015;6:72, http://dx.doi.org/10.3389/fendo.2015.00072

48. Wang H, Zhang K, Qin H, et al. Genetic association between angiotensinogen polymorphisms and lung cancer risk. Medicine (Baltimore). 2015;94(37):e1250, http://dx.doi.org/10.1097/MD.0000000000001250

49. Martin P, Noonan S, Mullen MP, et al. Predicting response to vascular endothelial growth factor inhibitor and chemotherapy in metastatic colorectal cancer. BMC Cancer. 2014;14:887, http://dx.doi.org/10.1186/1471-2407-14-887

50. Belyea BC, Xu F, Pentz ES, et al. Identification of renin progenitors in the mouse bone marrow that give rise to B-cell leukaemia. Nat Commun.2014;5 3273, http://dx.doi.org/10.1038/ ncomms 4273

51. Hu J, Zhang L-C, Song X, et al. KRT6 interacting with notch1 contributes to progression of renal cell carcinoma, and aliskiren inhibits renal carcinoma cell lines proliferation in vitro. Int $\mathrm{J}$ Clin Exp Pathol. 2015;8(8):9182-8.

52. Nguyen G. Renin, (pro)renin and receptor: an update. Clin Sci. 2011;120:169-78, http://dx.doi.org/10.1042/CS20100432

53. Müller DN, Binger KJ, Riediger F. Prorenin receptor regulates more than the renin-angiotensin system. Ann Med. 2012; 44(Suppl 1):S43-S48.

54. Shibayama Y, Fujimori T, Nguyen G, et al. (Pro)renin receptor is crucial for $\mathrm{Wnt} / \beta$-catenin-dependent genesis of pancreatic ductal adenocarcinoma. Sci Rep. 2015;5:8854, http://dx. doi.org/10.1038/srep08854

55. Kouchi M, Shibayama Y, Ogawa D, et al. (Pro)renin receptor is crucial for glioma development via the $\mathrm{Wnt} / \mathrm{b}$-catenin signaling pathway. J Neurosurg. 2017;127:819-28.

56. Han C-D, Ge W-S. Up-regulation of angiotensin-converting enzyme (ACE) enhances cell proliferation and predicts poor prognosis in laryngeal cancer. Med Sci Monit. 2016;22:4132-8, http://dx.doi.org/10.12659/MSM.896933
57. Yue Z, Yun-shan Z, Feng-xia X. miR-205 mediates the inhibition of cervical cancer cell proliferation using olmesartan. J Renin Angiotensin Aldosterone Syst. 2016;17(3):1-8, http://dx. doi.org/10.1177/1470320316663327

58. Tsai Y-P, Wu K-J. Hypoxia-regulated target genes implicated in tumor metastasis. J Biomed Sci. 2012;19(1):102, http:// dx.doi.org/10.1186/1423-0127-19-102

59. Tan W, Li Y, Lim S-G, Tan TMC. miR-106b-25/miR-17-92 clusters: polycistrons with oncogenic roles in hepatocellular carcinoma. World J Gastroenterol. 2014;20(20):5962-72, http://dx.doi.org/10.3748/wjg.v20.i20.5962

60. Cheng Y, Guo Y, Zhang Y, et al. MicroRNA-106b is involved in transforming growth factor $\beta 1$-induced cell migration by targeting disabled homolog 2 in cervical carcinoma. J Exp Clin Cancer Res. 2016;35:11, http://dx.doi.org/10.1186/s13046016-0290-6

61. Harb-De la Rosa A, Acker M, Swain S, Manoharan M. The role of epigenetics in kidney malignancies. Cent European J Urol. 2015;68(2):157-64, http://dx.doi.org/10.5173/ceju.2015.453

62. Semenza GL. The hypoxic tumor microenvironment: a driving force for breast cancer progression. Biochim Biophys Acta. 2016;1863(3):382-91, http://dx.doi.org/10.1016/j.bbamcr.2015.05.036

63. Yang X, So WY, Ma RC, et al. Diabetes and cancer: the mechanistic implications of epidemiological analyses from the Hong Kong Diabetes Registry. Diabetes Metab Res Rev. 2012;28 (5):379-87, http://dx.doi.org/10.1002/dmrr.2287

64. Reddy MA, Park JT, Natarajan R. Epigenetic modifications and diabetic nephropathy. Kidney Res Clin Pract. 2012;31 (3):139-50, http://dx.doi.org/10.1016/j.krcp.2012.07.004

65. Reddy MA, Natarajan R. Recent developments in epigenetics of acute and chronic kidney diseases. Kidney Int. 2015;88 (2):250-61, http://dx.doi.org/10.1038/ki.2015.148

66. Rodrigues-Ferreira S, Abdelkarim M, Dillenburg-Pilla P, et al. Angiotensin II facilitates breast cancer cell migration and metastasis. PLoS One. 2012;7(4):e35667, http://dx.doi.org/10.1371/journal.pone.0035667

67. Kemp JR, Unal H, Desnoyer R, et al. Angiotensin II-regulated microRNA 483-3p directly targets multiple components of the renin-angiotensin system. J Mol Cell Cardiol. 2014;75:25-39, http://dx.doi.org/10.1016/j.yjmcc.2014.06.008

68. de Oliveira da Silva B, Furtado Lima K, Gonçalves L, et al. MicroRNA profiling of the effect of the heptapeptide angiotensin-(1-7) in A549 lung tumor cells reveals a role for miRNA149-3p in cellular migration processes. PLoSOne. 2016;11(9):e0162094, http://dx.doi.org/10.1371/journal.pone. 0162094

69. Wang C, Guo D, Wang Q, et al. Aliskiren targets multiple systems to alleviate cancer cachexia. Oncol Rep. 2016;36(5): 3014-22, http://dx.doi.org/10.3892/or.2016.5118

70. Kaneko K, Ohba K, Hirose T, et al. Expression of (pro)renin receptor during rapamycin-induced erythropoiesis in $\mathrm{K} 562$ 
erythroleukemia cells and its possible dual actions on erythropoiesis. Tohoku J Exp Med. 2017;241:35-43, http://dx.doi. org/10.1620/tjem.241.35

71. Li XC, Hopfer U, Zhuo JL. Novel signaling mechanisms of intracellular angiotensin II-induced NHE3 expression and activation in mouse proximal tubule cells. Am J Physiol Renal Physiol. 2012;303(12):F1617-F1628, http://dx.doi.org/10.1152/ajprenal.00219.2012

72. Satou R, Gonzalez-Villalobos RA. The role of the JAK-STAT pathway in blood pressure and intrarenal renin-angiotensin system regulation. JAKSTAT. 2012;1(4):250-6, http://dx.doi. org/10.4161/jkst.22729

73. Sparks MA, Crowley SD, Gurley SB, et al. Classical renin-angiotensin system in kidney physiology. Compr Physiol. 2014;4(3):1201-28, http://dx.doi.org/10.1002/cphy.c130040

74. Shao W, Seth DM, Prieto MC, et al. Activation of the reninangiotensin system by a low-salt diet does not augment intratubular angiotensinogen and angiotensin II in rats. Am J Physiol Renal Physiol. 2013;304(5):F505-F514, http://dx.doi. org/10.1152/ajprenal.00587.2012

75. Zhuo JL, Ferrao FM, Zheng Y, Li XC. New frontiers in the intrarenal renin-angiotensin system: a critical review of classical and new paradigms. Front Endocrinol (Lausanne). 2013;4:166, http://dx.doi.org/10.3389/fendo.2013.00166

76. Ferrão FM, Lara LS, Lowe J. Renin-angiotensin system in the kidney: what is new? World J Nephrol.2014;3(3):64-76, http:// dx.doi.org/10.5527/wjn.v3.i3.64

77. Macconi D, Remuzzi G, Benigni A. Key fibrogenic mediators: old players. Renin-angiotensin system. Kidney Int Suppl. 2014; 4(1):58-64, http://dx.doi.org/10.1038/kisup.2014.11

78. Nangaku M, Hirakawa Y, Mimura I, et al. Epigenetic changes in the acute kidney injury-to-chronic kidney disease transition. Nephron. 2017;137:256-9. doi.org/10.1159/000476078

79. Zhuo JL. Augmented intratubular renin and prorenin expression in the medullary collecting ducts of the kidney as a novel mechanism of angiotensin II-induced hypertension. Am J Physiol Renal Physiol. 2011;301(6):F1193-F1194, http:// dx.doi.org/10.1152/ajprenal.00555.2011

80. Nguyen MTX, Han J, Ralph DL, et al. Short-term nonpressor angiotensin II infusion stimulates sodium transporters in proximal tubule and distal nephron. Physiol Rep. 2015;3(9):e12496, http://dx.doi.org/10.14814/phy2.12496

81. Ramkumar N, Stuart D, Calquin M, et al. Possible role for nephron-derived angiotensinogen in angiotensin-II dependent hypertension. Physiol Rep. 2016;4(1):e12675, http://dx.doi. org/10.14814/phy2.12675
82. Navar LG, Kobori H, Prieto MC, Gonzalez-Villalobos RA. Intratubular renin-angiotensin system in hypertension. Hypertension. 2011;57(3):355-62, http://dx.doi.org/10.1161/HYPERTENSIONAHA.110.163519

83. Li XC, Zhuo JL. Recent updates on the proximal tubule reninangiotensin system in angiotensin II-dependent hypertension. Curr Hypertens Rep. 2016;18(8):63, http://dx.doi.org/10.1007/s11906-016-0668-z

84. Kobori H, Harrison-Bernard LM, Navar LG. Urinary excretion of angiotensinogen reflects intrarenal angiotensinogen production. Kidney Int. 2002;61(2):579-85, http://dx.doi. org/10.1046/j.1523-1755.2002.00155.x

85. Alge JL, Karakala N, Neely BA, et al. Urinary angiotensinogen and risk of severe AKI. Clin J Am Soc Nephrol. 2013;8(2):18493, http://dx.doi.org/10.2215/CJN.06280612

86. Sørensen GV, Ganz PA, Cole SW, et al. Use of $\beta$-blockers, angiotensin-converting enzyme inhibitors, angiotensin II receptor blockers, and risk of breast cancer recurrence: a Danish Nationwide Prospective Cohort Study. J Clin Oncol. 2013; 31(18):2265-72, http://dx.doi.org/10.1200/JCO.2012.43.9190

87. Chae YK, Dimou A, Pierce S, et al. The effect of calcium channel blockers on the outcome of acute myeloid leukemia. Leuk Lymphoma. 2014;55(12):2822-9, http://dx.doi.org/10.3109/1 0428194.2014.901513

88. Nakai Y, Isayama H, Sasaki T, et al. No survival benefit from the inhibition of renin-angiotensin system in biliary tract cancer. Anticancer Res. 2016;36:4965-70, http://dx.doi.org/10.21873/anticanres.11065

89. Zhong Y, Chen EY, Liu R, et al. Renoprotective effect of combined inhibition of angiotensin-converting enzyme and histone deacetylase. J Am Soc Nephrol. 2013;24(5):801-11, http://dx.doi.org/10.1681/ASN.2012060590

90. Reddy MA, Sumanth P, Lanting L, et al. Losartan reverses permissive epigenetic changes in renal glomeruli of diabetic $\mathrm{db} / \mathrm{db}$ mice. Kidney Int. 2014;85(2):362-73, http://dx.doi.org/10.1038/ki.2013.387

91. Tang J, Zhuang S. Epigenetics in acute kidney injury. Curr Opin Nephrol Hypertens. 2015;24(4):351-8, http://dx.doi. org/10.1097/MNH.0000000000000140

92. Felipe AV, de Oliveira J, Chang PY, et al. RNA interference: a promising therapy for gastric cancer. Asian RAS J Cancer Prev. 2014;15(14):5509-15. doi.org/10.7314/APJCP.2014.15.14.5509

93. Van Beneden K, Mannaerts I, Pauwels M, et al. HDAC inhibitors in experimental liver and kidney fibrosis. Fibrogenesis Tissue Repair. 2013;6:1, http://dx.doi.org/10.1186/1755-1536-6-1 
Sažetak

\section{IZRAŽENOST SASTAVNICA SUSTAVA RENIN-ANGIOTENZIN KOD ONKOLOŠKIH BOLESTI}

\section{S. Dolomator, W. Zukow, N. Novikov, A. Markaryan i E. Eremeeva}

Analizirana je literatura posvećena promjenama u izraženosti RAS proteina stanica raka. Daje se kratak pregled dinamike izraženosti RAS proteina kod zloćudnih tumora i moguće uloge epigenetskih mehanizama u ovim procesima. Istraživanje epigenetskih mehanizama kod raka rezultiralo je razvojem bitno novih tehnika za njihovo ispravljanje, utemeljenih na primjeni selektivnih regulatornih sustava kovalentne modifikacije histona (npr. inhibitor deacetilaze) i tehnologije sinteze mikroRNA. Literaturni podaci pokazuju obećavajuće farmakološko ispravljanje epigenetske modifikacije kromatina u liječenju raka.

Ključne riječi: Onkologija; Ektopične RAS stanice raka; Epigenetska stimulacija RAS u onkologiji 